MUZIKOLOŠKI ZBORNIK - MUSICOLOGICAL ANNUAL XI, LJUBLJANA 1975

UDK 78(497.12):92 Osterc (093.32)

\title{
IZ KORESPONDENCE SLAVKU OSTERCU
}

\section{Dragotin C vetko (Ljubljana)}

Skladatelj Slavko Osterc je živel in delal $\mathrm{v}$ razmeroma utesnjenem nacionalnem in duhovnem vzdušju, ki ga je glasbeno bremenila še dediščina neposredne preteklosti in nazorsko precej omejene sedanjosti. Osterc se s pozno oziroma postromantično orientacijo ni hotel pomiriti. Uprl se ji je, prizadeval si je, da bi uresničil poslanstvo, ki si ga je bil zastavil za cilj in ki je bilo $\mathrm{v}$ tem, da slovensko glasbo idejno preusmeri in jo vključi, z njo vred pa tudi sebe, v evropski okvir. To je storil, nova naziranja so se $v$ njegovem času na Slovenskem naglo širila in tudi uveljavila $\mathrm{v}$ kompozicijski praksi. Ob tem so se tudi izvedbe sodobnikov s slovenskega in celotnega jugoslovanskega prostora doma in $\mathrm{v}$ tujini zelo pomnožile. Spet je bil Osterc ta, ki je tej množitvi mnogo prispeval s stiki, ki jih je imel $z$ domačimi in tujimi izvajalci, solisti in dirigenti, pa še $s$ skladatelji in kritiki. Za te stike je imel že po naravi vse sposobnosti, kontaktiranje mu je bilo nekako notranja potreba, ki je na pomembnosti pridobila, ko se je usmerila $\mathrm{v}$ konkretne naloge. Kje in kako bi lahko bilo kontaktiranje najbolj učinkovito, so mu kazali še zgledi njegovega vzornika Aloisa Hábe, $\mathrm{s}$ katerim so ga vezale iste ali sorodne težnje.

O tem nam marsikaj pove korespondenca iz Osterčeve zapuščine, ki se je sicer le delno ohranila, ${ }^{1}$ a je navzlic temu še vedno kar obsežna. ${ }^{2}$ Iz nje se bom omejil na tisto, ki se nanaša na stike tega skladatelja $\mathbf{s}$ tujimi glasbeniki, ${ }^{3}$ in skušal bom vsaj nakazati, kako so potekali. Pa tudi v tem želim biti selektiven. Vsi stiki namreč niso bili enako važni in vse, kar se je ohranilo iz Ostercu namenjene korespondence, ravno tako ni toliko značilno, da bi bistveno koristilo namenu tega prispevka.

1 Gl. Pokorn D., Bibliografski pregled kompozicij Slavka Osterca, MZ (Muzikološki zbornik) VI, 1970, 75.

2 Izvirno gradivo v NUKLj, rokopisni oddelek.

3 Osterčevi stiki z vrstniki na jugoslovanskem prostoru so bili po problematiki, ki so se je dotikali, kajpak v marsičem drugačni od onih s tujimi muziki. Tesni so bili zlasti z M. Milojevićem in J. Slavenskim ( $\mathrm{k}$ temu gl. D. Cvetko, Veze Josipa Slavenskog sa Slavkom Ostercom, Arti musices 1972, 63-76, in isti, Iz pisama Miloja Milojevića Slavku Ostercu, Spomenica SANU, knj. CD XXXIV, 1970, 265-276). 
Korespondenca, o kateri bo govor, zajema razdobje 1930-1940. Kar je navzven imel stikov prej, za to $\mathrm{v}$ zapuščini manjka sleherna dokumentacija. Gotovo pa so bili tudi pred nastopom tridesetih let, še zlasti s češkimi glasbeniki, kar govori tudi za ustrezno korespondenco. Te pa ni. Najbrž je ni imel za dovolj zanimivo in jo je zavrgel kot še marsikaj iz poznejšega časa.

Pisma, ki jih je Osterc pisal raznim naslovnikom, tu niso upoštevana, čeravno bi bila koristna za primerjavo in rekonstrukcijo, za katero pa je treba reči, da je mogoča vsaj delno tudi brez njih. Kaže, da jih vseh ne bo več mogoče dobiti, ${ }^{4}$ pa tudi dostopna niso v vsakem primeru..$^{5}$ Kolikor bodo na voljo, pa bodo dokumentacija, ki jo bo vredno preučiti in bo $\mathrm{v}$ prid osvetljevanju Osterčeve osebnosti in tudi slovenske, pa delno še evropske glasbene situacije zadnjega desetletja pred drugo svetovno vojno, kar vse poudarja potrebo po iskanju $\mathrm{v}$ tej smeri.

Med prvimi tujimi glasbeniki, s katerim se je Osterc vezal, so gotovo bili ti, ki jih je srečal v času svojega praškega šolanja (1925-1927). Mislim, da gre tu posebna vloga A. Hábi, ki je verjetno Osterca najprej opozorii na pomembnost Mednarodnega društva za sodobno glasbo (Société international de musique contemporaine-SIMC). Za sodelovanje $\mathrm{v}$ tem društvu pa ga je bržkone zadolžil J. Slavenski, čigar stiki s SIMC segajo že v leto 1922. S tem skladateljem so Osterčeve zveze izpričane vsaj od leta 1929 dalje. Slavenski mu je najprej zaupal delo v slovenski smeri jugoslovanske sekcije SIMC, odkoder je kmalu zatem Osterc razširil svojo dejavnost na jugoslovansko sekcijo kot celoto in jo nato usmeril še v centralo SIMC, ${ }^{6}$ ki je bila v Londonu. S slednjo je bil med leti 1932 in $1940 \mathrm{v}$ obsežnem dopisovanju: v njegovi zapuščini je 43 primerkov, pisem, dopisnic, okrožnic in podobnega gradiva, ki ga je dobil $\mathrm{s}$ te strani, kar pa najbrž ni vse in smemo domnevati, da se je mnogo izgubilo. Ta korespondenca se $v$ glavnem nanaša na razna zasedanja in priprave za mednarodne festivale in še na druga vprašanja organizacijske narave, posebno tista, ki so se tikala sodelovanja jugoslovanske sekcije SIMC v mednarodnem okviru. Gre ji bolj formalen kot vsebinski pomen in za naše razpravljanje ni kdove kaj zanimiva.

To pa ne spreminja pomena Osterčevega stika s centralo SIMC, ki je bil velik za vrsto drugih skladateljevih dejavnosti. Posredno ali neposredno je prispeval tudi $\mathrm{k}$ rezultatom, ki jih kažejo $\mathrm{v}$ raznih smereh Osterčeva prizadevanja izza tridesetih let.

Struktura SIMC je organizacijsko predvidela sodelovanje med nacionalnimi sekcijami in $\mathrm{v}$ tej zvezi zlasti izmenjalne koncerte. Osterc se je tej nalogi prizadevno posvetil, to dokazujejo njegove zveze $s$ poljsko,

$4 \mathrm{~K}$ temu prim. Cvetko D., Aus H. Scherchens und K. A. Hartmanns Korrespondenz an S. Osterc, Musicae Scientiae Collectanea-Festschrift K. G. Fellerer, Köln 1973, 70.

5 Prim. Cvetko D., Veze Josipa Slavenskog sa Slavkom Ostercom, ib., 63, 64.

6 Gl. isto, $66 \mathrm{ss}$.

$7 \mathrm{Kljub}$ zavzetosti, ki sta jo pokazala Osterc in Dénes Bartha (gl. gradivo ib.), z madžarskimi skladatelji ni prišo do trdnejšega sodelovanja, za katerega je dal spodbudo Osterc. Bartha mu je svetoval, naj se za izmenjavo obrne na budimpe- 
dansko, holandsko, argentinsko, avstrijsko in še zlasti $\mathbf{s}$ češkoslovaško sekcijo. ${ }^{8}$ Dopisovanje se je tako rekoč redno dotikalo vprašanja reprodukcije del sodobno usmerjenih skladateljev te in one strani in je večkrat privedlo do pozitivnih rezultatov. $\mathrm{V}$ nekaterih primerih je to tema. tiko preseglo in preraslo, rekel bi, $\mathrm{v}$ intimno kontaktiranje $\mathrm{s}$ posameznimi osebnostmi, čeravno se $\mathrm{z}$ vsemi Osterc osebno ni srečal. V njegov interesni krog so se tako vključevali novi sobesedniki.

Ohranjena korespondenca zaznamuje več pomembnih vrstnikov, ki se je z njimi skladatelj povezal po tej poti. Med njimi so bili npr. H. E. Apostel, P. Pisk, A. Casella in L. Dallapiccola..$^{9}$ Od zadnjega sta na razpolago dve pismi $\mathrm{z}$ dne 17. 12.1935 in 11.3.1936. V prvem pismu opozarja Osterca na svojo kompozicijo Divertissement in vprašuje: „Croyez-vous possible une présentation de mon petite ouvrage à Ljubljana?», iz drugega pa razberemo, da mu je Osterc na zastavijeno vprašanje odgovoril pritrdilno. Dallapiccola se mu je namreč zahvalil za "affectueuse amitié» in $\mathrm{mu}$ ob koncu dal vedeti, da pričakuje njegove "nouvelles«. Poleg teh so $\mathrm{v}$ vrsti novih sobesednikov še drugi, tako npr. Koffler, ki je v letih 1935-1938 precej vplival na množitev Osterčevih stikov, teh tudi z dirigen. tom G. Fitelbergom, ${ }^{10}$ nadalje Svend Chr. Felumb in Fritz Mahler, oba dirigenta iz Kopenhagena, katerih zanimanje je veljalo reproduciranju jugoslovanske glasbe nasploh in posebno Osterčeve, ${ }^{11}$ in J. C. Paz iz Buenos Airesa. Zanj vemo, da je Osterca visoko cenil ${ }^{12}$ in si v letih $1935-1940 \mathrm{z}$ njim pogosto dopisoval. Razen o izvedbah kompozicij jugoslovanskih avtorjev $\mathrm{v}$ Argentini ${ }^{13} \mathrm{mu}$ je pisal tudi o svojih novih delih, pa tudi o pogle-

štansko koncertno direkcijo, ki jo sestavljajo "lauter junge Leute, die im Geiste Bartóks wirken wollen und vor allem für die moderne Musik eintreten«, medtem ko za radio tega ni mogoče trditi, kajti tam so celo "Werke von Bartók nur äusserst selten gespielt", "von den jüngeren Komponisten ganz zu schweigenu. Dopisovanje med Bartho in Ostercom je iz začetka 1940, ko se je glede na evropske politične in vojne razmere dejavnost SIMC že občutno omejila in se je to zelo poznalo tudi $\mathrm{v}$ madžarskem glasbenem življenju.

8 Kolikor gre za češkoslovaško sekcijo SIMC, so bile Osterčeve zveze številnejše $\mathrm{s}$ posamezniki, ki pa so večidel imeli važno vlogo tudi v sami sekciji (Saružení pro soudobou hudbu - Přítomnost).

9 Največ stika je imel Osterc s P. Piskom, od katerega je v zapuščini 15 pisem in dopisnic iz časa 1934-1936. Ta je Osterca seznanjal tudi s tem, kar je ustvaril, kot pianist pa še s svojim reproduktivnim delom. V svoji korespondenci se torej ni omejil na formalna vprašanja kot npr. Apostel, Casella in v glavnem tudi Dallapiccola, če izvzamemo njegov interes, da bi Osterc posredoval izvajanje njegovih skladb $\mathrm{v}$ osrednjem slovenskem mestu.

$10 \mathrm{Iz}$ Kofflerjevih pisem Ostercu, ib., je to mogoče dobro razbrati.

11 Felumb je bil podpređsednik dansko-jugoslovanskega društva. Napisal je skladbo Esquisses yougoslaves za veliki orkester. $\mathrm{Na}$ Danskem je želel poleg Osterčevega Pihalnega kvinteta izvesti še wune suitie, rhapsodie ou fantaisie sur des mélodis populaires yougoslaves«. Prim. gradivo ib.

12 Prim. J. C. Paz, Introducción a la música de nuestro tiempo, Buenos Aires $1955,288-289$.

$13 \mathrm{Na}$ koncertih v Buenos Airesu je bila 16. 12. 1935 izvedena Osterčeva Toccata, 26. 6. 1936 Suita, 10. 12. 1937 pa Magnificat. Razen Osterčevih so bile na teh koncertih predstavljene še skladbe D. Žebrèta, J. Slavenskega, F. Šturma, D. švare in B. Leskovica, gl. gradivo ib. 
dih, ki jih je imel na umetniško ustvarjanje. ${ }^{14}$ Te je dobro karakteriziral tudi v pismu Ostercu z dne 1. 5. 1937. Tedaj se je ločil od skupine, ki jo je leta 1929 sam osnoval (Grupo reniovación), po njegovi stilizaciji zato, ker "mit den Ansichten und der Richtung einer Kollegen nicht einverstanden bin. Sie neigen ganz nach rechts, während ich der radikalen Richtung der modernen Musik angehöre«. $V$ istem pismu je še omenil, da računa $z$ Osterčevo podporo (»mit Ihrer wertvollen Unterstützung»). Nanjo se je pač lahko zanesel, Osterc se je tudi sam prišteval k radikalizmu, čeravno ga v svoji kompozicijski praksi ni vedno in dosledno realiziral, kar potrjuje njegov opus iz obdobja, ko se je orientiral $v$ novo, to je po praškem šolanju. Pazu je pomagal na razne načine. Posredoval mu je skladbe sodobnih slovenskih oziroma jugoslovanskih avtorjev, skrbel je za njegove neposredne stike $\mathrm{z}$ njimi, tako npr. $\mathrm{s}$ šturmom, Žebrètom in Papandopulom, ${ }^{15} \mathrm{~s}$ svojim vplivom je prispeval, da je bila Pazova Passacaglia sprejeta v program pariškega festivala SIMC. ${ }^{16}$ Pripravljenost za sodelovanje je bila intenzivna $z$ obeh strani, $z$ Osterčeve in Pazove. Navzlic daljavi, ki je ločila oba skladatelja, je izvrstno rezultirala.

$\mathrm{Ob}$ teh, ki sem jih doslej omenil, so nastajali še mnogi drugi stiki s tujimi komponisti. Poleg vloge, ki jo je imelo $s$ te strani Osterčevo povezovanje s centralo in posameznimi nacionalnimi sekcijami SIMC, so temu precej prispevala tudi razna srečanja na zasedanjih SIMC. Teh se je Osterc udeleževal kot sekretar njene jugoslovanske sekcije, navzoč pa je bil tudi na raznih festivalih SIMC, tako leta $1934 \mathrm{v}$ Firenzah in leta $1935 \mathrm{v}$ Pragi. $\mathrm{Ob}$ teh priložnostih je spoznal osebnosti, ki so bile vplivne in so bile $\mathrm{v}$ določeni meri zaslužne za njegovo prodiranje v mednarodni okvir. Med njimi so bili poleg nekaterih že navedenih muzikolog E. J. Dent, do leta 1938 predsednik SIMC, kritik E. Evans, ki je v tej funkciji nasledil Denta, zatem utemeljitelj francoske sekcije SIMC, muzikolog H. Prunières, skladatelj ruskega rodu V. Vogel, in še drugi. Iz gradiva, ki je v zapuščini, razberemo, da je bil $s$ posameznimi od teh $\mathrm{v}$ tesnejših stikih, tako zlasti $\mathrm{z}$ Dentom in Voglom. $Z$ Dentom so se njegove zveze utrdile zlasti ob srečanju v Parizu, kjer se je mudil v decembru 1936 kot član žirije za XV. festival SIMC.16a To članstvo $\mathrm{mu}$ je poleg koristi prineslo tudi marsikatero nevšečnost. Nanj so se namreč obračali razni komponisti in interpreti, da bi se zanje zavzel in bi se tako ali drugače vključili v program pariškega festivala. Med njimi je bil npr. skladatelj K. A. Hartmann, ki je v pismu z dne 9. 7. 1936 prosil Osterca, naj podpre kandidaturo njegovega Simfoničnega fragmenta za srednji glas in orkester, češ da bi bila to spričo tedanje politične situacije $v$ Nemčiji zanj »die einzige Möglichkeit überhaupt an

14 Prim. Pazovo pismo z dne 5. 4. 1938 Ostercu, ib.

15 Gl. pismo z dne 10. 8. 1937, ib.

$16 \mathrm{Na}$ to lahko sklepamo iz Pazovega pisma $\mathrm{z}$ dne 6. 2. 1937, ib.

16a Razen Osterca, Denta, Prunièresa, Vogla so bili v njej še drugi vidni glasbeniki, tako tudi Hába in E. Clark. Osterc je bil $\mathrm{v}$ tako žirijo pritegnjen že leto dni prej, ko so bile priprave za XIV. festival SIMC (Barcelona, 1936), vendar tedaj le kot namestnik člana. Takrat so bili člani oz. namestniki $\mathrm{v}$ žiriji tudi A. Webern, E. Ansermet, A. Casella in E. Křenek. Z njimi se je lahko srečal ob tej priložnosti ali ob drugih prireditvah SIMC. 
die Öffentlichkeit zu kommen«.17 Podobne želje je imel v Parizu živeči Jerzy Fitelberg, sin že omenjenega Grzegorza, ki je deloval v Varšavi. Z obema je bil Osterc že prej v stikih, Jerzyjev oče je na svojih koncertih izvajal tudi njegove kompozicije. Tako je še kar razumljivo, da je Jerzy Fitelberg upal, da mu bo Osterc pomagal, žiriji SIMC je namreč predložil svoj II. violinski koncert. V pismih $\mathrm{z}$ dne 19. in 25. 10. $1936 \mathrm{mu}$ je dal to vedeti in Osterc mu je zagotovil svojo podporo. ${ }^{18}$ Praški dirigent Karel Ančerl je Osterčevo podporo zanj osebno in za češkoslovaške skladatelje kar predpostavljal, kajti "wenn Du in der Jury bist, werden wir nicht zu kurz kommen mit unserer Musik, und es wird sich schon etwas für mich finden.$^{19}$ Tudi iz pisem, ki jih je novembra in decembra 1936 pisal Hába, zveni želja, da bi se Osterc zavzel za skladbe K. Reinerja, J. Bártoša, V. Polivke in litvanskega komponista Kačinskasa..$^{20}$ Razen teh so najbrž bili še drugi skladatelji in izvajalci, ki so se podobno zanašali na Osterca. Sklepi žirije pa niso bili odvisni samo od Osterca, ki je bil le eden izmed njenih članov. S svojim vplivom je $\mathrm{v}$ nekaterih primerih sicer uspel (Paz, J. Fitelberg, ${ }^{21}$ M. Milojević22), v vseh pa ne (Hartmann, Slavenski). V nekem primeru (Slavenski) je to vplivalo celo na bistveno spremembo $\mathrm{v}$ doslej tesnih odnosih.23

Stike navzven je pomembno širila še veljava, ki si jo je Osterc kot skladatelj čedalje bolj pridobival $\mathrm{z}$ izvedbami del $\mathrm{v}$ tujini, zlasti na festivalih SIMC. Vedno bolj je bil znan in priznan, zaželen je postajal za številne interprete, ki so si z njim tudi dopisovali, tako češkoslovaški izvajalci violist $J$. Beran, pianista $L$. Fuchsova in $\mathrm{K}$. Reiner in dirigent $\mathrm{K}$. Ančerl, fagotista A. Grdev (Sofia) in Giudice José Lo (La Plata). ${ }^{24}$ Ob teh in še mnogih nadaljnjih so bili zanj seveda še posebno interesantni nekateri dirigenti in solisti, ki so se že uveljavili v evropski glasbeni reprodukciji tridesetih let. Poleg stikov z G. Fitelbergom ${ }^{25}$ je treba $v$ tej zvezi navesti predvsem zveze, ki so bile med Ostercom in $\mathrm{H}$. Scherchnom in so rezultirale tako $\mathrm{z}$ natiskom kot izvedbo Osterčeve Plesne suite, ${ }^{26}$ pa po drugi strani tudi s Scherchnovim gostovanjem v Ljubljani (1937). Osterc si je dopisoval tudi s pianistom R. Koczalskim, ki je, na to sklepamo iz korespondence, ${ }^{27}$ poleg Kofflerja opozoril G. Fitelberga na Osterca, katerega kompozicije je cenil. V pismu z dne 16. 7. 1935 je Ostercu pohvalil njegove Arabeske, ki da pri podrobnem študiju mnogo pridobijo, "namentlich

$17 \mathrm{~K}$ temu prim. op. 3 .

18 Gl. izvirnik ib.

19 Gl. Ančerlovi pismi $\mathrm{z}$ dne 18. 9. in 23. 12. 1936, ib.

20 Prim. pisma A. Hábe $z$ dne 2. 11., 22. 11., 3. 12. in 26. 12. 1936, ib.

21 G1. pismo G. Fitelberga $z$ dne 29. 12. 1936, ib.

22. Prim. Cvetko D., Iz pisama Miloja Milojevića Slavku Ostercu, ib.

23 G1. Cvetko D., Veze Josipa Slavenskog s Slavkom Ostercom, ib.

$2+$ Prim. gradivo ib.

25 Gradivo ib.; Cvetko D., Aus G. und J. Fitelbergs Korrespondenz an S. Osterc ( $\mathrm{v}$ tisku).

$25 \mathrm{Z}$ naslovom Trois danses orientales je izšla $\mathrm{v}$ založbi Ars viva (BruxellesZürich), skladatelj jo je posvetil Scherchnu. V zvezi $\mathrm{z}$ njenim natiskom prim. gradivo ib.

27 G1. pismo R. Koczalskega $z$ dne 18. 8. 1935, ib. 
durch den menschlichen-innigen Stoff. Ich kenne keine Musik, die weniger auf ,Effekt' berechnet ist, wie diese und das gerade ist das Wesentliche! Ich werde für Ihr Werk alles tun, was in meinen Kräften steht« - laskavo mnenje, ki je toliko tehtnejše, če upoštevamo, da je prišlo izpod peresa subtilnega interpreta Chopinovih klavirskih kompozicij. Za Osterčevo Sonato za saxofon in klavir pa se je navdušil Sigurd Rascher, ki mu je bila ta skladba tudi posvečena. V pismu Ostercu $\mathrm{z}$ dne 14. 6. 1935 je omenil, da je prepričan, da je omenjena Sonata wein sehr gutes Stück, das ich im Laufe der Zeit oft spielen werde«. V vrsti interpretov, s katerimi si je Osterc dopisoval, je bil tudi bolgarski pianist in skladatelj P. Vladigerov, s katerim je imel zvezo vsaj že v letu 1937.28 Ko je le-ta imel v letu $1940 \mathrm{v}$ Ljubljani svoj recital in je Ljubljanska filharmonija predstavila njegovo simfonično rapsodijo Vardar,,$^{29} \mathrm{mu}$ je Osterc posvetil svojo klavirsko Fantasie chromatique.

Navedeni stiki so bili različno važni, ti bolj oni manj. Ostercu so pomagali odpirati vrata $\mathrm{v}$ svet, interesantni pa so bili tudi za nekatere njegove sobesednike. On je namreč večkrat vplival, da so bila dela kakega skladatelja iz tega kroga uvrščena $\mathrm{v}$ programe festivalov SIMC ali da je ta in oni solist nastopil $\mathrm{v}$ tem okviru. Posredoval je tudi gostovanja tega in onega interpreta $\mathrm{v}$ Ljubljani (npr. Scherchen, Reiner, Fuchsova, Vladigerov) in še drugod na jugoslovanskem glasbenem prostoru.

V širini, ki je značilna za Osterčevo kontaktiranje prek meja, imajo, tako se zdi, posebno mesto njegovi stiki s Prago. ${ }^{30} \mathrm{Z}$ naprednimi češkimi

$28 \mathrm{~V}$ zapuščini je gradivo skromno, a je moralo biti dopisovanje med Ostercom in Vladigerovom obsežnejše. Srečavala sta se tudi na mednarodnih zasedanjih in prireditvah SIMC, Osterc je v veliki meri prispeval $\mathrm{k}$ obisku Vladigerova v Ljubljani leta 1940.

29 Gl. Jutro (Ljubljana), 22. 4. 1940.

30 Gradivo, ki je na voljo, pove marsikaj. Obsega korespondenco, pa še izrezke iz časnikov in revij, ki vselej niso opremljeni $\mathrm{s}$ potrebnimi podatki. Gre seveda predvsem za kritike o kompozicijah, ne samo za češke, tudi za druge. Teh je moralo biti mnogo, dokumentacija zanje pa je $\mathrm{v}$ ostalini skromna. $\mathrm{V}$ tridesetih letih je Osterc doživel izvedbe $\mathrm{v}$ raznih zahodnoevropskih mestih in drugod. Posebno nekatere njegove skladbe so bile kar precejkrat na koncertnih odrih, tako Toccata, Aforizmi, Sonata za saxofon in klavir, Klasična uvertura, Mouvement symphoniqe, Suita, Hábi posvečen Koncert za klavir in pihala, Passacaglia in koral, Nonet. Zanj je bila interesantna sleherna izvedba in ravno tako kritika, saj je $\mathrm{v}$ tem in onem videl rezultat svojih naporov, realizacijo svojih ustvarjalnih idej in nov uspeh. Zdi se, da je izjemno pozornost posvetil poročilom o Koncertu za klavir in pihala, ki so izšla po izvedbi na XIII. festivalu SIMC (Praga 1935), in o Nonetu po njegovi praški izvedbi 22. 4. 1938, na katerega je že prej opozoril $\mathrm{H}$. W. Susskind (gl. Rytmus 1937, 88). To delo, ki sodi po strukturi med avtorjeve najznačilnejše kompozicije s komornega področja, je krstil Český Nonet, Praga pa ga je sprejela in ocenila s priznanjem (gl. gradivo ib:). Za Osterca je bila njegova praška izvedba spodbudna vsaj iz dveh razlogov: zato, ker je predstavljal $\mathrm{v}$ dvanajsttonskem sistemu grajen in atematično zasnovan Nonet nov dosežek $v$ njegovem ustvarjanju, in še zato, ker je uspel $\mathrm{v}$ mestu, ki je imelo $\mathrm{v}$ razvijanju in širjenju nove glasbe skorajda vodilno vlogo $v$ evropskem okviru. Zanimivo bi bilo vedeti, kaj je Osterca napotilo, da je ta svoj opus posvetil A. Honnegerju. Pač zato, ker ga je cenil kot skladatelja, drugačnih interesov $v$ tem primeru ni mogel imeti. Dopisovanje med njima je bilo, tako sklepamo iz ohranjenega gradiva, omejeno na Osterčevo sporočilo Honeggerju o posvetilu in pošiljko kompozicije, in na Honeggerjevo pismo Ostercu $z$ dne 12. 10. 1937, ko se je ta za- 
skladatelji se je čutil eno. Številni so mu bili zelo blizu in so imeli nanj določen vpliv, vsekakor večji kot drugi glasbeniki, s katerimi se je tudi vezal. Tu pa je vendar treba opozoriti, da je bil Osterc zelo samostojen in kritičen in se ni dal kar tako vplivati. Vplivom, ki so prihajali od zunaj, gre tako le relativna pomembnost. Vsklajal jih je s svojim pojmovanjem, tudi v primerih, ko so bili praškega izvora.

Ob Ančerlu, ${ }^{31}$ Fuchsovi $^{32}$ in Reinerju, ${ }^{33}$ ki jim gre iz omenjenega kroga poudarjena vloga, gre $\mathrm{v}$ nakazanem smislu posebno mesto Hábi. Zanj smemo po tem, kar je $\mathrm{v}$ tej zvezi znano, trditi, da je na Osterca najizdatnejše vplival. ${ }^{34}$ Sprva še na relaciji učitelja in učenca sta se Hába in Osterc čedalje bolj približevala in postopoma tudi spoprijateljila. O tem zgovorno pripoveduje ohranjena korespondenca, zlasti ta od leta 1932 dalje. Hába je, in to upravičeno, v Ostercu videl privrženca naziranj, ki jih je oznanjal, še več, človeka, ki jih bo na južnoslovanskem prostoru tudi širil. Seznanjal ga je s svojim delom, se zanimal za njegovo, hvalil, kar mu je Osterčevega ugajalo, pa tudi pokazal na to, kar ga je motilo. Na dopisnici, ki mu jo je namenil z dnem 20.3. 1934, je na primer o njegovem Koncertu za klavir in pihala dejal, da je to "krásná, vzletná (schwungvoll) a lapidární skladba", a je v nadaljevanju izrazil željo, naj ne dela več sekvenc $v$ netematičnem slogu in naj čimprej napiše kompozicijo v dvanajsttonskem zvoku, za kar je prepričan, da lahko izvrstno opravi. Podobno vrednotenje Osterčevih del je razvidno še iz nekaterih drugih Hábovih pisem, iz katerih ravno tako razberemo, da je bil z njimi zadovoljen in ga je impresioniralo zorenje njihovega avtorja. Kako in kaj misli o njih, je večkrat tudi javno pove-

hvalil za to in ono in pristavil: "... j'ai pu me rendre compte de tout l'intérêt de votre composition et vous en félicite vivement» (izvirnik ib.).

$31 \mathrm{Med}$ Ančerlom in Ostercom je bilo živo dopisovanje, gl. gradivo ib. Ančerl je s Čško filharmonijo izvedel tudi Osterčevo Passacaglio in koral (20. 1. 1937, Praga), za katero se je zanimal že 1935 (prim. pismo z dne 14. 10. 1935). Po izvedbi je v pismu Ostercu $\mathrm{z}$ dne 24. I. 1937 med drugim omenil, da misli, „dass wir die Passacaglia gut herausgebracht haben, obzwar es ein Stuick ist, das unsere Abonenten nicht sehr begeistertu. Iz nadaljevanja kaže, da so bile kritike različne: "Wie Du auch aus den Referaten entnehmen kannst, war die erste (moderne) Hälfte meines Programmes allen ,problematisch'». Ob njihove avtorje se je Ančerl drastično spotaknil: "Es herrscht jetzt bei uns auch eine starke Reaktion. Und diese Schweine schreien schon, wenn man einen Namen, welcher etwas für den Fortschritt der Musik bedeutet, nur aufführt."

32 Osterčevi stiki z L. Fuchsovo segajo v leto 1936, ko je ta izrazila željo, da bi se seznanila $z$ njegovimi skladbami (gl. pismo z dne 30. 4. 1936, ib.). Poslej se je med njima razvila obsežna korespondenca, $v$ cit. zapuščini je 27 pisem in razglednic iz časa 1936-1938. Fuchsova je večkrat izvajala njegova klavirska dela, zlasti Aforizme, $\mathrm{ki}$ jih $\mathrm{ji}$ je avtor posvetil, Toccato in tudi skladbe drugih jugoslovanskih skladateljev. Osterc je posredoval, da je na pariškem festivalu izvedla Milojevićeve Ritmične grimase.

33 Stiki med Reinerjem in Ostercom so dokumentirani za čas 1933-1939, v zapuščini je 44 Reinerjevih pisem in dopisnic. $V$ njih je Reiner Ostercu izpovedoval tudi svoja gledanja na interpretacijo moderne glasbe (npr. v pismu z dne 4. 7. 1934), na praški skladateljski krog in Hábovo četrttonsko šolo (prim. pismo $\mathrm{z}$ dne 19. 11. 1934). Tu in tam si je dovolil tudi kritične pripombe $\mathrm{k}$ nekaterim Osterčevim kompozicijam, kar pa ni vplivalo na njune stike, ki so bili ves čas prijateljski, pristni.

$34 \mathrm{~V}$ cit. zapuščini se je ohranilo 26 Hábovih pisem in dopisnic Ostercu iz razdobja 1931-1939, a jih je gotovo bilo precej več, gl. gradivo ib. 
dal. Tako je npr. Ostercu v pismu z dne 21. 2. 1933 sporočil, da je v nekem svojem predavanju ob navzočnosti vseh atematikov (!) govoril o možnostih spreminjanja klasičnih tipov form $\mathrm{v}$ svobodne forme in kot dober primer za to navedel njegov Kvintet za pihala, ki ga je za ta namen tudi analiziral. $\mathrm{V}$ omenjenem pismu je še zapisal, da je Osterc »doch eine frische schöpferische Potenzı. S tem, da je opozarjal na kvaliteto njegovih skladb, mu je posredoval vrsto nadaljnjih stikov, tako s Kofflerjem, Rascherjem, V. Talichom. Ravno on, Hába, se zdi ta, ki je Ostercu od vseh ne samo posredno s svojim zgledom, ampak tudi neposredno in najbolj učinkovito prispeval $\mathrm{k}$ uveljavitvi $\mathrm{v}$ mednarodnem okviru. Imel je srečo. $\mathrm{V}$ Ostercu je našel enakovreden značaj, ki svojega vzornika ni zatajil in mu je vračal, kar je bilo v njegovi moči. Hába pa je bil že sredi tridesetih let v evropski glasbi sodobne orientacije pojem in mu za afirmacijo seveda ni bilo treba to kar Ostercu. Ta pa se je zanj v tej smeri vseeno trudil, predvsem tako, da je svoje učence pošiljal v Hábovo kompozicijsko šolo in skrbel za izvedbo skladb na slovenskem in jugoslovanskem glasbenem prostoru.

$\mathrm{V}$ okvir sodelovanja med Hábo in Ostercom, ki je bogato rezultiralo, še spada nek načrt, ki sicer nikoli ni bil realiziran, kot je bil zamišljen, a je zaradi koncepta značilen. Spodbudila ga je težnja, da bi bila slovanska glasba na festivalih SIMC bolj zastopana kot doslej in bi se organizirali še posebni festivali sodobne slovanske glasbe, in nadalje, da bi se poleg češkoslovaške, poljske in jugoslovanske sekcije SIMC osnovali še enaki sekciji v Bolgariji in Sovjetski zvezi. Časovno pada ta načrt $\mathrm{v}$ konec leta 1934, ko je nastal osnutek dogovora med Hábo kot predstavnikom češkoslovaške in Kofflerjem kot predstavnikom poljske sekcije SIMC, Osterc pa naj bi skupaj z M. Milojevićem še poskrbel za soglasje jugoslovanske vrstnice, ${ }^{35}$ za kar se je tudi zavzel in formalno uredil, kolikor je bilo treba, da bi bil dogovor sporazumen. ${ }^{36}$ Sporazum naj bi bil dokončno oblikovan ob XV. festivalu SIMC v Pragi leta 1935, prvi festival slovanske glasbe pa decembra istega leta $\mathrm{v}$ Varšavi. Jedro opisane zamisli je seveda bilo v idejnem usmerjanju glasbene produkcije vseh slovanskih narodov. Kaže, da bi naj k njeni realizaciji bistveno prispeval Osterc, ki je, če že ne takrat, pa vsaj nekoliko pozneje, imel zveze z Vladigerovom. Koliko mu je uspelo navezati stike $\mathbf{s}$ kakim vrstnikom iz Sovjetske zveze in ali si je $\mathrm{v}$ tedanji politični situaciji $\mathrm{v}$ tej smeri sploh prizadeval - med Jugoslavijo in Sovjetsko zvezo takrat še ni bilo diplomatskih stikov -, pa je vprašanje, ki ga podrobneje ni mogoče osvetliti, gradivo je za to premalo konkretno. Rahla domneva pa je dopustna. Violinist Victor de Winterfeld ${ }^{37}$ je namreč

25 Omenjeni osnutek navaja $v$ tč. 2 (॥Zweck der Verständigung»): a) Gemeinsames Vorgehen im Rahmen der I.G.N.M. so, dass die slavische Musik auf den Festspielen genügend und entsprechend vertreten wird; b) Kunstaustausch; c) Festspiele zeitgenössischer slavischer Musik." V tč. 3 tega osnutka pa je pod b navedeno: "Die Entstehung neuer slavischer Sektionen anregen werden, wo solche nicht vorhanden sind (Bulgarien, SSSR?)«, prim. gradivo ib. (IGNM Internat. Ges. für neue Musik).

36 Gl. nedatirano pismo $\mathrm{v}$ gradivu ib.

$37 \mathrm{~V}$ cit. pismu, ib., je Winterfeld omenil, da je absolviral glasbeno visoko šolo v Berlinu in bil učenec Georga Kulenkampffa. Leta 1935 je imel 22 let, na dopisnici iz Bydgoszcza, ki jo je pisal Ostercu in je datirana z 19. 11. 1936, se je 
$\mathrm{v}$ pismu Ostercu $\mathrm{z}$ dne 25. 2. 1935, torej $\mathrm{v}$ letu, ko se je snoval prej omenjeni načrt, navedel, da je slišal, "dass Sie durch die internationale Gessellschaft für neue Musik in Verbindung stehen mit russischen Persönlich. keiten«. Je temu res bilo tako? Ni šlo morda za Vladimira Vogla, ki je bil sicer rojen v Moskvi, pa ni živel in delal v Sovjetski zvezi? Osterc je imel z njim dobre stike. Karkoli je že bilo, za zdaj vsekakor ni dokumentacije, ki bi potrdila njegove zveze $\mathrm{s}$ tem ali onim sovjetskim skladateljem. Tudi ne s Prokofjevim, kateremu je posvetil svojo baletno pantomimo Illusions. Kaj neki ga je privedlo $\mathrm{k}$ temu dejanju? Gotovo tudi in zlasti opus tega ustvarjalca. Morda pa še kaj drugega. Omenjeno posvetilo datira namreč iz začetka leta 1941, ko je Osterc napeto spremljal potek političnih in vojnih dogodkov v Evropi in svoje simpatije odločno usmeril na sovjetsko stran. ${ }^{38}$ Kar verjetno se mi zdi, da je tudi to imelo močan delež $\mathrm{v}$ njegovi odločitvi za posvetilo Prokofjevu. $\mathrm{Mu}$ je še lahko poslal prepis Illusions $\mathrm{z}$ vpisanim posvetilom in pismo s sporočilom o spoštovanju, ki ga je gojil nasproti njemu in njegovi glasbi? V to skoraj ni mogoče dvomiti. Vprašanje se zdi le, ali je to in ono tudi prišlo v roke Prokofjevu in ali $\mathrm{mu}$ je ta v pozitivnem primeru spričo vojnih razmer, ki so sledile tako rekoč neposredno zatem, sploh še utegnil odgovoriti. Virov, ki bi o tem kaj povedali, ni.

Iz ohranjene korespondence, ${ }^{39} \mathrm{ki}$ dokazuje nevezano, a vendar smotrno širino, lahko ugotovimo še nadaljnje Osterčeve stike $z$ glasbeniki izven njegove ožje in širše domovine ${ }^{40} \mathrm{Ti}$ so rezultirali enako ali podobno kot že omenjeni. Iz celotne dokumentacije, ki je na voljo, sledi, da so skladateljeve zveze s posameznimi glasbeniki navzlic svoji številnosti na splošno trajale daljša obdobja, včasih kontinuirano tudi skozi več let, in da so iz Evrope segle tudi v Latinsko Ameriko. ${ }^{41} \mathrm{~V}$ podjetnosti, ki jo je po tej strani

deklariral kot Jugoslovan. Bil je brez zaposlitve in pripravljen, da gre $\mathbf{v}$ Sovjetsko zvezo, če bi tam kje dobil mesto koncertnega mojstra ali vsaj prvega violinista. Osterc $\mathrm{mu}$ je svetoval, naj se obrne na V. Vogla (gl. dopisnico z dne 28. 3. 1935, ib.). Verjetno na Voglov nasvet je očividno pisal v Sovjetsko zvezo, a kaže, da brez uspeha, kajti na dopisnici $\mathrm{z}$ dne 19. 11. 1936 pravi: "Aus Russland habe ich leider nichts gehört.ı

38 To je Osterc izrazil tudi s tem, da je svojo simfonično pesnitev Mati leta 1940 posvetil prvemu sovjetskemu poslaniku v Jugoslaviji, V. A. Plotnikovu, Sonate pour violoncelle et piano pa leta 1941, vsekakor pred aprilom, sovjetskemu diplomatu V. Saharovu. Gradivo gl. ib.

39 Medsebojno dopisovanje je večidel teklo v nemščini, jeziku, ki ga je Osterc izvrstno obvladal, redkeje $\mathrm{v}$ drugih jezikih. Celo njegovi češki vrstniki so mu pisali $\mathrm{v}$ tem jeziku in ne $\mathrm{v}$ svojem, čeravno je bil Osterc $\mathrm{v}$ češčini dobro verziran.

40 Med drugimi npr. tudi s K. B. Jirákom. Osterc mu je izrazil željo, da bi na londonskem festivalu SIMC (1938) on dirigiral njegov Mouvement symphonique, ki mu ga je posvetil. $\mathrm{K}$ temu gl. Jirákovi pismi $\mathrm{z}$ dne 3. 10. 1936 in 26. 2. 1938, ib. - Nikjer pa ni v gradivu kakega pisma J. Suka, ki mu je Osterc posvetil svoj II. godalni kvartet (1934). Gotovo mu ga je tudi poslal in mu o tem še posebej pisal, za kar se je Suk po vsej verjetnosti zahvalil.

41 Osterčeve zveze so segle tudi v Urugvaj. V njegovi zapuščini je poleg pisem J. C. Paza iz Buenos Airesa tudi korespondenca, ki jo je na Osterca naslavljal F. C. Lange iz Montevidea. Ta je Osterca prosil za sodelovanje $\mathrm{v}$ Boletinu latino americano de musica, ki ga je urejal. Iz gradiva sklepamo, da se je Osterc vabilu odzval. Lange, $\mathrm{ki}$ je tudi bil orientiran $\mathrm{v}$ sodobno glasbo tridesetih let in je zasledoval podobne cilje kot npr. Paz, je Ostercu sugeriral tudi izmenjalne koncerte 
pokazal, ni Osterca dosegel, kaj šele presegel nihče od dotedanjih slovenskih skladateljev. V korespondiranju je bil hiter in natančen in imel je oster čut za to, $\mathbf{s}$ kom dopisovanje ni izguba časa. $\mathbf{S}$ tem nočem reči, da bi hotel kontaktirati samo z ljudmi, ki so mu lahko bili koristni kot izvajalci ali ocenjevalci njegovih kompozicij, čeravno so ti imeli pri njem prednost, kar je razumljivo. Vendar je iz dokumentacije, ki nam je $\mathrm{v}$ mislih, razvidno tudi to, da je šel čez ta interesni dejavnik. V svojih pismih je razpravljal tudi o problemih nove glasbe, upravičenosti in vlogi, $\mathrm{ki} \mathrm{ji}$ gre $\mathrm{v}$ razvoju. $\mathrm{K}$ temu nas navaja stilizacija pisem, $\mathrm{ki}$ jih je dobival od drugod in ki je bila očitna reakcija na določene pasuse njegovih tekstov. Analogno se nam iz obstoječih virov kar ponuja sklep, da je Osterc, čeravno redko, temu ali onemu sobesedniku vsaj nakazal, če že ne čisto razkril, svoje osebne, intimne probleme, ki sicer z njegovim ustvarjanjem niso imeli neposredne zveze, a so na nek način nanj gotovo tudi vplivali.

Najbolj intenzivni so bili Osterčevi stiki s tujim glasbenim svetom med leti 1934 in 1938, ko je bil poudarjeno aktiven $v$ raznih smereh in je doživ1jal $\mathrm{v}$ mednarodnem svetu s svojimi skladbami čedalje več uspehov. ${ }^{42} \mathrm{Ti}$ so se nadaljevali tudi zatem, ko so se vsakršni stiki vedno bolj ožili, za kar sta bila vsaj dva razloga. Osterčevo zdravje, ki že prej ni bilo zadovoljivo, ${ }^{43}$ se je slabšalo. Čeravno se je bolezni na vso moč upiral in hitel s komponiranjem, kot bi čutil, da se mu čas izteka, je ta manjšala njegove želje za kontaktiranjem. Postopnemu zapiranju njegovega interesnega kroga pa je prispevala tudi evropska politična situacija, zaradi katere se je po letu 1938 delokrog SIMC naglo ožil. To in ono je vplivalo, da je Osterčevo dopisovanje in sodelovanje navzven pospešeno usihalo44 in ga,

v sorodni obliki, kot jo kažejo tedanja argentinska prizadevanja. Prim. njegovi pismi Ostercu z dne 8. 8. in 17. 10. 1935, ib.

42 Mednje štejejo tudi natiski njegovih skladb $\mathrm{v}$ tujih založbah (UniversalEdition, Edition Ars viva), gl. gradivo ib.

$43 \mathrm{~V}$ tej zvezi so zanimiva nekatera pisma S. Rascherja, ki potrjujejo, da je bolezen ovirala Osterca že leta 1935. Znanci so jo pripisovali drugim vzrokom, kot so ti zares bili. Tudi Rascher je bil med njimi. Vpraševal ga je, če je dovolj "sparsam mit Alkohol" in pristavil, da je wals Mensch eigentlich viel zu wertvoll und ernsthaft, um über dieses Bein zu stolpern«. Bil je antropozof oz. teozof, $\mathrm{v}$ istem pismu $\mathrm{z}$ dne 19. 10. 1935 je Osterca vpraševal: „Kennen Sie das Buch ,Theosophie' von Rudolf Steiner? Ich glaube, das ist gerade das, was für Sie das Richtige wäre, oder ,Wie erlangt man Erkenntnisse der höheren Welt' von Rudolf Steiner." Svetoval mu je, naj bere ti knjigi "ganz langsam, in kleinen Stücken, jeden Tag ein bischen in naj mu o tem piše. Kaže, da se za te nasvete Osterc ni zmenil, Rascher se je namreč v pismu $\mathrm{z}$ dne 11. 12. 1935 znova vrnil $\mathrm{k}$ tej temi. Hotel je vedeti, ali je Steinerja bral in kak vtis je napravil nanj. Seveda je imel najboljši namen ("Ich möchte Sie noch lange haben», ib.), a Osterc je bil v svojem bistvu ateist in Steinerju tuj. Še Hába, ki je sicer tudi bil vnet Steinerjev privrženec, po tej strani ni imel nanj nobenega vpliva.

44 Med njegovimi zadnjimi sobesedniki je bil Hába. $\mathrm{V}$ pismu $\mathrm{z}$ dne 6. 6. 1939 je Ostercu previdno pisal, kako je z njim. Njegova šola za četrttonsko glasbo na praškem konservatoriju je postala po zasedbi Prage vprašljiva, to, kar je on oznanjal, je sodilo $\mathrm{v}$ sentartete Kunstu. Apeliral je, da bi mu Osterc poskrbel kakega učenca, češ da je kontinuiteta važna za obe strani, v nadaljevanju pa je pisal: "Ich halte meine gesamte Arbeit aufrecht. Musikverein ,Pŕitomnost' tut nächste Saison im bescheiderenen Rahmen vorzubereiten. Das Frühlingswetter war miserabel und kalt. Jetzt beginnt es heller und wärmer zu werden. Das 
čeravno je v njem hotel vztrajati do svojega konca, že $v$ letu 1940 in še posebno neposredno zatem skoraj več ni bilo.45

\section{SUMMARY}

The Slovene comṕoser Slavko Osterc (1895-1941), the central figure of modern Slovene music and prominent in the European musical trends of the thirties, dedicated part of his activities to the International Society for Contemporary Music. He was active at its meetings, and in 1937 was member of the programme-jury for the Society's 15th festival held in Paris. His compositions were often performed at the festivals of this international organization and due to his frequent as well as successful appearance on the concert programmes abroad his fame grew. All this brought him into contacts with the European musical scene, as is evident from the correspondence preserved. Thus it appears that he endeavoured to organize exchange concerts for the promoting of new music, about which he wrote to individual musicians, explaining to them his personal views on contemporary stylistic trends.

He corresponded with the ISCM centre in London, with its national sections (Czechoslovak, Polish, Austrian, Italian, French, Spanish, Danish, Dutch, Argentinian), as well as with various domestic and foreign personalities. Among the latter were H. E. Apostel, P. Pisk, A. Casella, L. Dallapiccola, G. Fitelberg, J. C. Paz, E. J. Dent, E. Evans, K. A. Hartmann, H. Scherchen, R. Koczalski, K. B. Jirák, A. Honneger and others, especially A. Hába, his former teacher at the Prague Conservatory, and model, with whom he coopertated closely and who, among all the others, influenced him to the greatest extent. There is no concrete evidence about contacts with S. Prokofiev, though there might have been some, even if cursory, at the time when Osterc dedicated his ballet Illusions to the great master. Apart from Prokofiev, Osterc dedicated his compositions also to other personalities such as H. Scherchen, A. Hába, K. B. Jirák, J. Suk, S. Rascher, A. Honneger, $K$. Reiner and $P$. Vladigerov. His contacts were most intensive during the period 1934-1938, when his diverse activities were strongest and successes in the field of composition greatest, which is partly proven also by the fact that foreign publishers (Universal Edition, Ars viva) printed some of his compositions. After 1938 Osterc's contacts with the musical life became fewer and fewer. At least because of two reasons. His health, not very good for a number of years, deteriorated quickly. At the same time, the political situation in Europe grew worse and worse, impairing the ISCM fields of activity. Both facts influenced Osterc's contacts to such a degree that by 1940 they had nearly completely withered away.

repariert auch das Gemüt und Lebensartı - s tem je gotovo mislil na marčne dogodke 1939 in to, kar je sledilo. Česar ni razločno napisal on, je storil $\mathbf{M}$. Ristić, ki je v pismu Ostercu $\mathrm{z}$ dne 25. 8. $1939 \mathrm{v}$ zvezi $\mathrm{s}$ Hábo in problemom obstoja njegove šole dejal, da ujedan od najbitnijih uslova da on a $s$ njim četvrttonska klasa dalje $u$ tome ustavu radi je da ima i iduće školske godine strance kod sebe, $u$ prvom redu Jugoslovene«, prim. cit. pismo, ib.

45 Iz tega časa, nekaj pred zlomom Francije, je še pismo z dne 3. 4. 1940, ki ga je na Osterca naslovila pariška Association de la Revué Musical $\mathrm{z}$ vabilom, da bi $\mathrm{v}$ njenem komiteju sprejel sodelovanje. $\mathrm{V}$ le-tem so bile pomembne osebnosti, tako npr. A. Cortot, P. Claudel, S. Lifar, P. Valéry, D. Milhaud. Tudi cit. povabilo govori o veljavi, ki jo je imel Osterc $\mathrm{v}$ mednarodnih glasbenih krogih. 